of the satisfactory working of the Ladies' Educational Associa. tion, recently decided to open the Faculties of Arts and Law and of Science to women.

Again, there is a very general demand for increased facilities of instruction in engineering and other branches of applied science, which can nowhere be so efficiently met as in connection with a fourishing scientific school like that of University College. Lastly, the numbers of the school have for some years been steadily increasing, and it is not unreasonable to hope that it may soon outgrow its present space. On all these grounds an urgent necessity is now imposed upon the college to undertake a considerable enlargement of its buildings.

Application for tickets should be made to the Jubilee Celebration Committee as early as possible.

University College, London, June i8

TALFOURD ELY, Secretary

\section{Examination of Small Organisms in Water}

IN order to examine the minute organisms that inhabit water, such as rotifers, vorticellæ, and kindred microzoons, the arrangement I proposed some years ago in the Quart. Fourn. of Micros. Sci. will, I believe, be found most convenient. This is to inclose the objective in a brass or other metal tube having its lower end closed by a piece of thin microscopic glass coming close up to but not touching the object-glass. With this protection we can plunge the end of the microscope into a small tank, filled with water, containing the small living organisms, and examine them at our leisure for days or even weeks. The thin glass plate immersed in the water gives us a perfectly steady, flat watersurface, which is not disturbed by any agitation of the surfacewater of the tank. Objectives of an inch, half an inch, a quarter of an inch, and even an eighth of an inch focus, may be thus used under water, and all the trouble of catching and ensmaring the small animals is thus avoided. This invention I first employed for the examination of morbid secretions, such as urine. I have since employed it for watching the operations of minute creatures that inbabit water, which may thus be seen in their natural habitat and under normal conditions, which is not the case when they are seen in the usual way, between the two layers of glass on an ordinary microscopic slide. Any optician can make such a tube to screw over the objective of any microscope, and, though it can readily be removed and applied, its presence does not interfere with the use of the microscope in air.

53, Montagu Square, W.

R. E. DUDGEON

\section{THE LATE MR. HEIVITSON}

THE memory of the warm-hearted gentleman abovenamed deserves a passing notice in these columns, for the effect of his labours on at least one department of natural history bas been great. William Chapman Hewitson, who died at Oatlands, near Walton-on-Thames, on May 28 last, aged seventy-two years, was by birth a Northumbrian, and, after the somewhat rough education of a Westmoreland school, took up the calling of a surveyor. His passion for natural history was exhibited in very early life, and, after some years' practice of his profession, the fortunate inheritance of a competence, and something more, from an uncle saved him the necessity of pursuing a distasteful rocation, and enabled him to indulge his fancy practically without stint. In 183I, while still engaged in his professional duties, he projected his "British Oology," the first part of which appeared in April, "I 831 , and the last in 1838 . As he himself subsequently wrote :-

"The book was itself as migratory as the birds, the eggs of which are depicted in its pages; many of the plates were drawn at night after a long day of railway surveying in the fields, and the letter-press was printed wherever the author happened to be stationed at the time. There were few collectors to aid him in those days, and it is with a grateful feeling he remembers now the helping hand which was then held out to him by his friend Mr. Yarrell.'

Yet the work was a great success. Such beautiful figures of eggs-all drawn on stone by the author-had never before been seen, for his touch was as delicate as his eye was correct, and great care was bestowed upon the colouring. His zeal for the task he had undertaken, led him with two friends, one of whom was Mr. John Hancock-perhaps the best ornithologist now living-to visit Norway and explore its coasts in quest of those many British birds, of the nidification of which nothing was known except that it was not carried on in these islands. This expedition in 1833 to a country hitherto so little explored by Englishmen as Norway, was no small proof of enterprise, and, with the simultaneous attempt, with a like intent, made in Iceland by Mr. G. C. Atkinson, bore good fruit, not merely in its immediate results, but even long afterwards; for it was doubtless the example of these gentiemen ${ }^{2}$ that prompted the subsequent exertions of Wolley, Hudleston, Salvin, Tristram, and others; while the successes in recent years of Alston, Harvie Brown, Danford, and Seebohm, may also be traced to the same cause. The influence has even extended to the United States, as witness the explorations conducted by Kennicott, Macfarlane, and their indefatigable successors under the authority of the Smithsonian Institution. The result has been that the true home of almost every species of bird which inhabits Europe at any time of the year has been discovered, and the same with a large number of those which inhabit North America, and thus, of course, has accrued a great gain to ornithology.

Mr. Hewitson, however, did not pretend to foresee this sequel to his enterprise and that of his friends. His aim was far humbler. In his own words :-

"However unimportant in itself the branch of natural history which I have attempted to elucidate, the beautiful and varied objects which compose it are amongst the first to excite the imagination and call forth in boyhood those feelings, that love for nature, which are inherent in us all; and however the cares or the pleasures of after life may have erased those earlier feelings, there are few who have not one day derived pleasurable emotions from their contemplation, and who do not remember those joyous times when, at the first breaking loose from school, they have hastened to the wood and the hedgerow in search of their painted prize."

The "British Oology" was soon out of print and a second edition was called for, which, under the title of "Coloured Illustrations of the Eggs of British Birds," was begun in 1842 (when the author took the opportunity of publishing a Supplement to his former issue) and finished in 1846 , while in 1853 -only eleven years latera third edition was demanded. This, completed in 1856 , remains unquestionably the best publication on the subject; for, though the plates were not so carefully coloured as in the second edition, the number of species represented, chiefly owing to the discoveries of Wolley, was largely increased. But in the meanwhile Hewitson's taste had turned towards another department. He had begun with his usual energy that wonderful collection of diurnal Lepidoptera, and works in illustration of that group, with which his name will be always associated, and by which it will probably be most widely known. His villa at Oatlands, with its beautiful view and charm. ing garden, was a sight not to be forgotten, to say nothing of the glorious contents of his cabinets. Here he passed the last twenty-five years of his life, or more; seldom leaving home, always glad to welcome a visitor whose tastes agreed with his own, and occasionally returning to his old "flame," when he could thereby assist a friend-as witness some of the plates in the earlier volumes of The Ibis. The promulgation and subsequent prevalence of the doctrines of evolution, however, greatly disturbed him; and perhaps the only thing that ruffled his temper was to hear that one naturalist after another had embraced what to him seemed a pestilent heresy.

${ }^{1}$ It is fair to mention that in $18_{3}$ Hoy began a series of tours into the Netherlands with the same object, and in $18_{3}$ x Salmon made an egg-collecting voyage to Orkney and Shetland, but the places they visited bore no comparison in remoteness and difficulty of travelling to those above-mentioned. 